\title{
ARIOPHANTA HUBERI THACH, 2018 IS NOT A PULMONATE, BUT A JUVENILE POLLICARIA ROCHEBRUNI (MABILLE, 1887) (GASTROPODA: CYCLOPHOROIDEA: PUPINIDAE)
}

\author{
BARNA PÁlL-GERGELY ${ }^{*}$, ANDRÁS HUNYADI ${ }^{2}$ \\ ${ }^{1}$ Plant Protection Institute, Centre for Agricultural Research, Hungarian Academy of Sciences, Budapest, \\ Hungary (e-mail: pall-gergely.barna@agrar.mta.hu) \\ ${ }^{2}$ Adria sétány $10 \mathrm{G} 2 / 5$., Budapest 1148 , Hungary \\ *corresponding author \\ ABSTRACT: Two new synonyms of the pupinid Pollicaria rochebruni (Mabille, 1887) are recognised here. \\ Namely, Hybocystis balansai Mabille, 1889, and Ariophanta huberi Thach, 2018. The former was found in \\ the collection of the Muséum National d'Histoire Naturelle (Paris), and was not included in the recent \\ revision of the genus Pollicaria, whereas the latter was described based on a single juvenile shell somewhat \\ reminiscent of a helicarionid shell.
}

KEY WORDS: synonym, taxonomy, Vietnam, land snail

THACH (2018) described three new genera and 132 species and subspecies of molluscs, mainly from Southeast Asia. Among them, he named Ariophanta huberi Thach, 2018 based on a single specimen. However, the holotype of A. huberi is a juvenile Pollicaria rochebruni (Mabille, 1887) (Pupinidae, Caenogastropoda), not an Ariophanta (Ariophantidae, Heterobranchia) (BOUCHET et al. 2017). Additionally, here we report another synonym of $P$. rochebruni (Hybocystis balansai Mabille, 1889), which was not included in the recent revision of Pollicaria (KONGIM et al. 2013).

\section{TAXONOMIC PART}

\section{Class: Gastropoda}

Subclass: Caenogastropoda

Superfamily: Cyclophoroidea Gray, 1847

Family: Pupinidae L. Pfeiffer, 1853

Genus: Pollicaria Gould, 1856

Pollicaria Gould 1856: 14.

Pollicaria rochebruni (Mabille, 1887)

Hybocystis rochebruni MABILLE 1887: 12.
Hybocystis balansai Mabille, 1889 new synonym

Pollicaria rochebruni, KONGIM et al. 2013: 35-37, figs 5D-E, 6E.

Ariophanta huberi Thach, 2018 (THACH 2018: 41, figs 548-549 (4 figs)) new synonym

Material examined: Mt. Bavy (Tonkin) [Ba Vì Mountain Range, northern Vietnam, northwest of Hanoi], Muséum National d'Histoire Naturelle, Paris, France (MNHN) (2 syntypes of Hybocystis balansai; Fig. 1); no locality, 2 syntypes of Hybocystis 

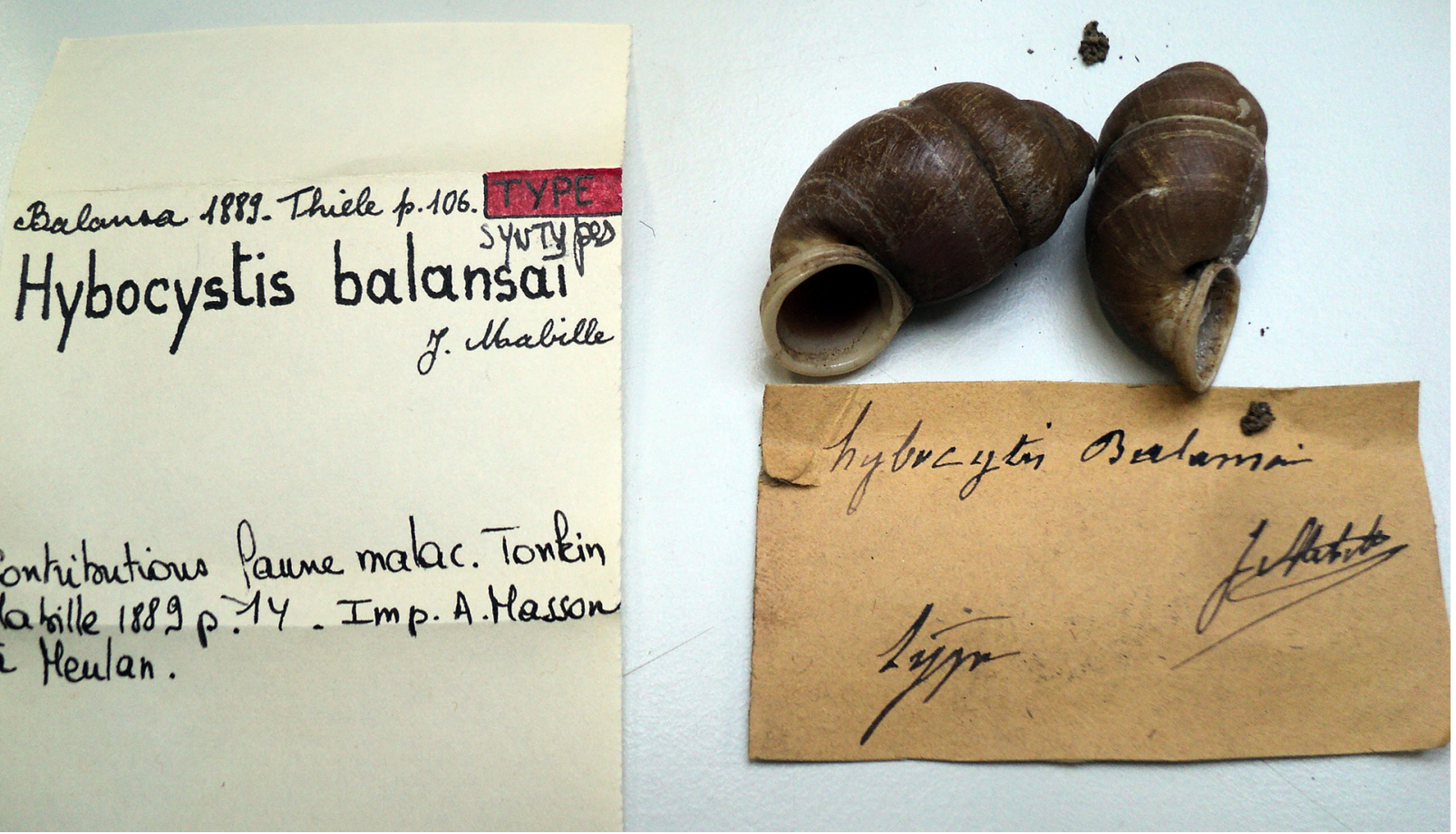

Fig. 1. Syntypes of Hybocystis balansai Mabille, 1889 (synonym of Pollicaria rochebruni (Mabille, 1887))

balansai, MNHN; Ninh Hòa District, Khánh Hòa Province, Vietnam, holotype of Ariophanta huberi (MNHM-IM-2000-34094).

Remarks: The holotype of Ariophanta huberi is a juvenile Pollicaria shell. A similar mistake was made by BENSON (1856), who described a juvenile shell of Pollicaria gravida (Benson, 1856) as Otopoma blennus Benson, 1856 (BENSON 1859, KONGIM et al. 2013).

Ariophanta huberi was described from Ninh Hòa District, Khánh Hòa Province of southern Vietnam. The geographically closest Pollicaria species is Pollicaria rochebruni (Mabille, 1887), which is reported from the vicinity of Da Nang (approx. $430 \mathrm{~km}$ from the type locality of Ariophanta huberi). Although the geographic distance and the juvenile condition of the holotype leaves some doubts about the identity of "Ariophanta huberi", the size, shell colour and the generally large distributional area of Pollicaria species suggest that it is a synonym of $P$. rochebruni.

\section{REFERENCES}

BENSON W. H. 1856. Characters of seventeen new of the Cyclostomacea from the British Provinces of Burmah, collected by Theobald W., jun., Esq. Annals and Magazine of Natural History Series 2, 17: 225-233. https://doi.org/10.1080/00222935608697501

BENSON W. H. 1859. Observation of shell and animal of Hybocystis, a new genus of Cyclostomidæ, based on Megalostoma gravidum and Otopoma Blennus, B.; with notes
Ariophanta huberi Thach, 2018, and Pollicaria huberi Thach, 2018, become secondary homonyms, because the former is described based on a juvenile Pollicaria shell. As First Revisers, we give precedence to the name Pollicaria huberi Thach, 2018, over the name Ariophanta huberi Thach, 2018, so we do not need to give replacement name for Ariophanta huberi Thach, 2018. The validity of Pollicaria species described by THACH (2018) are not discussed in this note.

\section{ACKNOWLEDGEMENTS}

We are very grateful to VIRGINIE HÉros and PHILIPPE MAESTRATI for granting access to the collection of the MNHN. PHILIPPE BOUCHET discussed nomenclatural issues with us. This study was supported by the MTA (Hungarian Academy of Sciences) Premium Post Doctorate Research Program for BPG.

on other living shells from India and Burmah. Annals and Magazine of Natural History Series 3, 4: 90-93. https://doi.org/10.1080/00222935908697091

BOUCHET P., ROCROI J. P., HAUSDORF B., KAIM A., KANO Y., NÜTZEL A., PARKHAEV P., SCHRÖDL M., STRONG E. E. 2017. Revised classification, nomenclator and typification of gastropod and monoplaco- 
phoran families. Malacologia 61: 1-526. https://doi. org/10.4002/040.061.0201

Gould A. A. 1856. [Dr. A. A. Gould presented the following descriptions of Shells]. Proceedings of Boston Society of Natural History 6: 11-16.

GRAY J. E. 1847. A list of genera of recent Mollusca, their synonyma and types. Proceedings of the Zoological Society of London 15: 129-219.

Kongim B., Sutcharit C., NAGgS F., PANHA S. 2013. Taxonomic revision of the Elephant Pupinid snail genus Pollicaria Gould, 1856 (Prosobranchia, Pupinidae). ZooKeys 287: 19-40. https://doi.org/10.3897/zookeys.287.4617

MABILLE J. 1887. Molluscorum Tonkinorum Diagnoses. A. Masson, Meulan.
MABILLE J. 1889. Contributions à la faune macalogique [sic!] du Tonkin. A. Masson, Meulan.

PFEIFFER L. 1853. Catalogue of Phaneropneumona or terrestrial operculated Mollusca in the collection of the British Museum. Woodfall \& Kinder, London.

THACH N. N. 2018. New shells of South Asia. Seashellslandsnails-freshwater shells. 3 new genera, 132 new species \& subspecies. 48HRBooks Company, Akron, Ohio, USA.

Received: November 6th, 2017

Revised: November 10th, 2018

Accepted: November 14th, 2018

Published on-line: December 11th, 2018 